\title{
Purification and characterization of GlcNAc-6-P 2-epimerase from Escherichia coli K92
}

\author{
Miguel Ángel Ferrero ${ }^{\bowtie}$, Honorina Martínez-Blanco, Federico Felino Lopez-Velasco, Car- \\ los Ezquerro-Sáenz, Nicolas Navasa, Sofia Lozano and Leandro B. Rodríguez-Aparicio ${ }^{\bowtie}$
}

Departamento de Biología Molecular, Universidad de León, Campus de Vegazana, León, Spain

Received: 12 April, 2007; revised: 15 May, 2007, accepted: 08 June, 2007

available on-line: 14 June, 2007

\begin{abstract}
$\mathrm{N}$-Acetylmannosamine (ManNAc) is the first committed intermediate in sialic acid metabolism. Thus, the mechanisms that control intracellular ManNAc levels are important regulators of sialic acid production. In prokaryotic organisms, UDP- $N$-acetylglucosamine (GlcNAc) 2-epimerase and GlcNAc-6-P 2-epimerase are two enzymes capable of generating ManNAc from UDP-GlcNAc and GlcNAc-6-P, respectively. We have purified for the first time native GlcNAc-6-P 2-epimerase from bacterial source to apparent homogeneity (1200 fold) using Butyl-agarose, DEAE-FPLC and Mannose-6-P-agarose chromatography. By SDS/PAGE the pure enzyme showed a molecular mass of $38.4 \pm 0.2 \mathrm{kDa}$. The maximum activity was achieved at $\mathrm{pH} 7.8$ and $37^{\circ} \mathrm{C}$. Under these conditions the $K_{\mathrm{m}}$ calculated for GlcNAc-6-P was $1.5 \mathrm{mM}$. The 2-epimerase activity was activated by $\mathrm{Na}^{+}$ and inhibited by mannose-6-P but not mannose-1-P. Genetic analysis revealed high homology with bacterial isomerases. GlcNAc-6-P 2-epimerase from E. coli $\mathrm{K} 92$ is a ManNAc-inducible protein and is detected from the early logarithmic phase of growth. Our results indicate that, unlike UDP-GlcNAc 2-epimerase, which promotes the biosynthesis of sialic acid, GlcNAc-6-P 2-epimerase plays a catabolic role. When $E$. coli grows using ManNAc as a carbon source, this enzyme converts the intracellular ManNAc-6-P generated into GlcNAc-6-P, diverting the metabolic flux of ManNAc to GlcNAc.
\end{abstract}

Keywords: $N$-acetylglucosamine, sialic acid, capsular polysialic acid, 2-epimerase

\section{INTRODUCTION}

$\mathrm{N}$-Acetylneuraminic acid (NeuAc) is an acidic sugar present in prokaryotic (capsular polysaccharides and lipopolysaccharides) and eukaryotic (glycoproteins and glycolipids) organisms and plays an essential role in many biological recognition processes (Reuter et al., 1982; Rodriguez-Aparicio et al., 1992; Rutishauser, 1993; Revilla-Nuin et al., 1998a; Maru et al., 2002; Bork et al., 2005; Tanner, 2005).

The biosynthetic pathway of NeuAc has been extensively studied and in both eukaryotic and prokaryotic cells $\mathrm{N}$-acetylmannosamine (ManNAc) is the essential sugar precursor (Corfiel \& Schauer, 1982; Van Rinsum et al., 1983; Rodriguez-Apari- cio et al., 1992; Vann et al., 1993; Maru et al., 2002; Chou et al., 2003; Tanner, 2005; Viswanathan et al., 2005). In this biosynthetic process, at least three different amino sugar 2'-epimerases have been implicated in ManNAc metabolism: UDP- $\mathrm{N}$-acetylglucosamine (GlcNAc) 2-epimerase (EC 5.1.3.14); GlcNAc 2-epimerase (EC 5.1.3.8), and GlcNAc 6-phosphate 2-epimerase (EC 5.1.3.9). In eukaryotic cells, UDPGlcNAc 2-epimerase and GlcNAc 2-epimerase have been implicated in the synthesis and catabolism of sialic acid, respectively (Hinderlich et al., 1997; Stasche et al., 1997; Luchansky et al., 2003). In both cases, the enzymes have been extensively studied and their biological significance established (Maru et al., 1996; Hinderlich et al., 1998; Itoh et al., 2000;

Corresponding authors: Leandro B. Rodríguez-Aparicio and Miguel Ángel Ferrero, Departamento de Biología Molecular, Universidad de León, Campus de Vegazana, 24007 León, Spain; tel.: (34 98) 7291212 1227; fax: (34 98) 729 1226; e-mail: leandro.redriguez@unileon.es; ma.ferrero@unileon.es

Abbreviations: Asn, asparagine; GlcNAc, N-acetyl-D-glucosamine; GlcNAc-6-P, N-acetyl-D-glucosamine 6-phosphate; ManNAc, $N$-acetyl-D-mannosamine; NeuAc, $N$-acetylneuraminic acid; PA, polysialic acid; PTS, phosphotransferase transport system; Xyl, xylose. 
Blume et al., 2004; Noguchi et al., 2004). Prokaryotic organisms lack GlcNAc 2-epimerase activity (Plumbridge \& Vimr, 1999) and UDP-GlcNAc 2-epimerase and GlcNAc-6-phosphate 2-epimerase have been related to the synthesis and catabolism of sialic acid, respectively (Plumbridge \& Vimr, 1999; Walters et al., 1999; Ringenberg et al., 2003; Murkin et al., 2004; Vann et al., 2004). Bacterial UDP-GlcNAc 2-epimerase is a protein encoded by the neuC gene, which catalyzes the conversion through hydrolysis of UDPGlcNAc into ManNAc and UDP in the first step of the both sialic acid biosynthesis pathways (Ringenberg et al., 2003; Murkin et al., 2004; Vann et al., 2004). GlcNAc-6-P 2-epimerase catalyzes the isomerization of GlcNAc-6-P to ManNAc-6-P (Grosh \& Roseman, 1965; Rodríguez-Aparicio et al., 1999). In this case, the activity of the enzyme has been specifically detected in different bacterial sources (Grosh \& Roseman, 1965; Rodríguez-Aparicio et al., 1999) and siaA from Neisseria meningitides B and nanE from Escherichia coli have been proposed as the putative encoding genes (Plumbridge \& Vimr, 1999; Petersen et al., 2000; Kalivoda et al., 2003). Here we describe for the first time the purification and characterization of the GlcNAc-6-P 2-epimerase present in E. coli K92. Its physiological role in the regulation of the intracellular pool of free sialic acid and the modulation of capsular polysialic acid biosynthesis are also discussed.

\section{MATERIALS AND METHODS}

Chemicals. N-acetyl-D-neuraminic acid (NeuAc), N-acetyl-D-mannosamine (ManNAc), Nacetyl-D-glucosamine (GlcNAc), N-acetyl-D-glucosamine-6-phosphate, mannose-1-phosphate, mannose6-phosphate, pyruvate, D-xylose $(\mathrm{Xyl})$, L-asparagine (Asn), bovine serum albumin (BSA), 2-thiobarbituric acid, periodic acid, streptomycin sulphate, alkaline phosphatase type III from Escherichia coli, NeuAc lyase from Clostridium perfringens, Butyl-agarose and Mannose-6-phosphate-agarose were purchased from Sigma Chemical Co. Sephacryl S-200, Sephadex G25 (PD-10) and $\left[1-{ }^{14} \mathrm{C}\right]$-pyruvic acid $(28 \mathrm{mCi} / \mathrm{mmol})$ were from GE-Healthcare. Other reagents used were of analytical quality.

Microorganisms, plasmids and growth conditions. Bacterial strains were maintained on Trypticase Soy Agar (Difco) and slants grown for 8-12 h at $37^{\circ} \mathrm{C}$ were used for seeding liquid media. E. coli K92 (ATCC 35860) was grown in Xyl-Asn or ManNAc-Asn liquid media, as previously described (González-Clemente et al., 1990; Revilla-Nuín et al., 1998b). E. coli BL21 (DE3) and DH5 $\alpha$ were grown in Luria-Bertani (LB) (Sambrook et al., 1989) medium at $37^{\circ} \mathrm{C}$. Recombinant E. coli BL21 (DE3) and DH5 $\alpha$ cells were cultured in the same medium supplemented with kanamycin $(25$ to $50 \mu \mathrm{g} / \mathrm{ml})$. The plasmid used in this work was pET-42b(+) (Novagen). Cellular incubations were carried out on a rotary shaker at $37^{\circ} \mathrm{C}$ for the time required.

GlcNAc-6-P 2-epimerase assays. GlcNAc-6$\mathrm{P}$ 2-epimerase activity was evaluated using an assay coupled to NeuAc synthesis, as previously described (Rodríguez-Aparicio et al., 1999). Briefly, the incubation mixture contained the following in a final

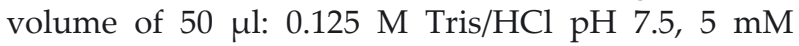
GlcNAc-6-phosphate; $10 \mathrm{mM} \mathrm{MgSO}_{4}, 10 \mathrm{mM} \mathrm{NaCl}$ and protein extract. After incubation at $37^{\circ} \mathrm{C}$ for 30 $\mathrm{min}$, the reaction was stopped by cooling on ice. The enzymatically generated ManNAc-6-phosphate was dephosphorylated to ManNAc and coupled to $\mathrm{NeuAc}$ synthesis by simultaneous addition of $1 \mathrm{U}$ of alkaline phosphatase, $8.75 \mathrm{mM}$ of pyruvate and 0.05 $\mathrm{U}$ of NeuAc lyase from C. perfringens (Sigma). The final volume of this reaction was $60 \mu \mathrm{l}$ and after incubation at $37^{\circ} \mathrm{C}$ for $30 \mathrm{~min}$ (or the required time) the NeuAc synthesized was quantified colorimetrically according to the 2-thiobarbituric acid methodology (Warren, 1959) described elsewhere (Rodríguez-Aparicio et al., 1999).

GlcNAc-6-phosphate 2-epimerase activity was also evaluated by a radiometric assay using commercial radioactive pyruvate $(1 \mu \mathrm{Ci})$. In this case, the NeuAc generated was chromatographed and evaluated by scintillation counting (Rodríguez-Aparicio et al., 1987). In all cases, reaction mixtures without GlcNAc-6-P or with boiled protein extracts $\left(95^{\circ} \mathrm{C}\right.$ for $10 \mathrm{~min}$ ) were used as controls.

One unit of each enzyme was defined as the amount of 2-epimerase that synthesizes $1 \mathrm{nmol}$ of ManNAc-6-phosphate/min at $37^{\circ} \mathrm{C}$ under each assay condition. Specific activity (SA) was expressed as units/milligram of protein.

For enzymatic quantification, in all cases control 2-epimerase reaction assays containing heat-denatured protein extracts were used as blanks. In the colorimetric reactions, we also used reaction mixtures without substrate (GlcNAc-6-P or pyruvate) as controls.

6-P-Gluconolactonase assay. 6-P-Gluconolactonase activity was evaluated using the Kupor and Fraenkel assay (1969) as described by Thomason et al. (2004).

Proteins were measured by the method of Bradford (1976), using BSA as standard.

Polysialic acid determinations. The sialylpolymer produced by E. coli K92 was analyzed by the Svennerholm methodology (1958) described elsewhere (Rodríguez-Aparicio et al., 1988).

Purification of GlcNAc-6-P 2-epimerase. E. coli was grown in the ManNAc-Asn-defined chemical medium up to $\mathrm{OD}_{540}=2.5$. Bacteria were 
collected by centrifugation $\left(10000 \times g, 10 \mathrm{~min}\right.$ at $\left.2^{\circ} \mathrm{C}\right)$, washed twice with saline solution, and resuspended in $50 \mathrm{mM}$ Tris/ $\mathrm{HCl}$ buffer, $\mathrm{pH}$ 7.6. Cells $(20 \mathrm{~g}$ wet mass $/ 100 \mathrm{ml}$ of buffer) were subjected to four rounds of sonication (30 s of sonication followed by $30 \mathrm{~s}$ on ice in a model B12 Branson:Sonifier) and the homogenate was centrifuged at $17000 \times \mathrm{g}, 10 \mathrm{~min}$ at $2^{\circ} \mathrm{C}$. The pellet was discarded and the supernatant fluid was treated with $0.75 \%$ streptomycin sulphate to remove the nucleic acids. After centrifugation $\left(17000 \times \mathrm{g}, 10 \mathrm{~min}\right.$ at $\left.2^{\circ} \mathrm{C}\right)$, the supernatant was treated with ammonium sulphate. The protein fraction precipitating at $45 \%$ (containing $96 \%$ of GlcNAc-6$\mathrm{P}$ 2-epimerase activity) was collected by centrifugation $\left(17000 \times g, 15 \mathrm{~min}\right.$ at $\left.2^{\circ} \mathrm{C}\right)$. The pellet was then dissloved in $50 \mathrm{mM}$ Tris/ $\mathrm{HCl}(\mathrm{pH} 7.5)$, and passed through a Sephadex G-25 (PD-10) column to eliminate the excess of ammonium sulphate. Ammonium sulphate was added to the desalted extract to $35 \%$ saturation and applied to a column $(10 \times 2 \mathrm{~cm})$ of Butyl-agarose (from Sigma) equilibrated with the same buffer containing ammonium sulphate (25\% satn.). The proteins were eluted with $30 \mathrm{ml}$ of a linear gradient of ammonium sulphate $(25-0 \%$ satn.) in $50 \mathrm{mM}$ Tris/ $\mathrm{HCl}$ buffer, $\mathrm{pH}$ 7.5. Fractions containing maximal enzyme activity were pooled, desalted by passing through a PD-10 column, and subjected to DEAE-FPLC chromatography. Two protein pool fractions from the Butyl-agarose chromatography were introduced into an FPLC system (Waters-Millipore) equipped with an anion exchange column (Waters Protein Pack DEAE 8HR 1000 A $8 \mu \mathrm{m}$ : 10 x $100 \mathrm{~mm}$ ) equilibrated with $50 \mathrm{mM}$ Tris/ $\mathrm{HCl}$ buffer, $\mathrm{pH}$ 7.5. After a wash with the same buffer, the proteins were eluted with a 0 to $0.18 \mathrm{M} \mathrm{NaCl}$ linear gradient and fractions $(1 \mathrm{ml})$ were collected and assayed for GlcNAc-6-P 2-epimerase activity. Fractions containing maximal enzyme activity were equilibrated against Tris/ $\mathrm{HCl}$ buffer $10 \mathrm{mM}, \mathrm{pH}$ 8.0, desalted (PD-10 column chromatography) and introduced on a mannose 6-phosphate-agarose column $(10 \times 5 \mathrm{~mm})$ equilibrated with $10 \mathrm{mM}$ Tris/ $\mathrm{HCl}$ buffer, $\mathrm{pH}$ 8.0. After a wash with $5 \mathrm{ml}$ of the same buffer, GlcNAc6-P 2-epimerase was eluted with $2 \mathrm{ml}$ of $25 \mathrm{mM}$ Tris/ $\mathrm{HCl}, \mathrm{pH} 8.0$, containing $0.5 \mathrm{M} \mathrm{NaCl}$. Fractions of $0.5 \mathrm{ml}$ that contained the maximum enzyme activity were tested in a $12 \%$ SDS/PAGE system.

Using this procedure the GlcNAc-6-P 2-epimerase of E. coli was purified 1200 fold (see Table 1).

Electrophoretic analyses. SDS/polyacrylamide gel electrophoresis (SDS/PAGE) (Laemmli, 1970) was performed in $12 \%$ slab gels under reducing conditions. Phosphorylase $b\left(M_{\mathrm{r}} 94000\right)$, bovine serum albumin $\left(M_{\mathrm{r}} 67000\right)$, ovalbumin $\left(M_{\mathrm{r}} 43000\right)$, carbonic anhydrase $\left(M_{\mathrm{r}} 30000\right)$, soybean trypsin inhibitor $\left(M_{\mathrm{r}}\right.$ $20100)$ and $\alpha$-lactalbumin $\left(M_{\mathrm{r}} 14000\right)$ were used as relative molecular mass standards.
Agarose gels were between $0.8 \%$ and $1.0 \%$ according to the procedure of Sambrook et al. (1989). The DNA markers used to estimate the size of unknown DNA were $1 \mathrm{~kb}$ DNA Plus Ladder (Invitrogen) and Lambda DNA/Hind III (Promega).

Amino acid sequencing. The purified enzyme was desalted by HPLC on a Vydac reverse phase 5$\mu \mathrm{m}$ C-4 column (type 214TP54, $0.46 \times 25 \mathrm{~cm}$ ) using a $30 \mathrm{~min}$ linear gradient $(1 \mathrm{ml} / \mathrm{min})$ from 20 to $95 \%$ acetonitrile $(0.1 \%$ trifluoroacetic acid present). The protein was dissolved in $30 \mu \mathrm{l}$ of $0.15 \%$ trifluoroacetic acid and loaded onto the sequencer. Amino acid sequencing was carried out as described elsewhere (Hewick et al., 1981).

Tryptic digestion and mass spectrometry analyses of protein. A gel piece from SDS/PAGE containing purified GlcNAc-6-P 2-epimerase was carefully excised and washed twice in water. Protein was reduced in-gel, alkylated and digested with trypsin according to Shevchenko et al. (2000). Briefly, the gel piece was washed twice with water, shrunk for $15 \mathrm{~min}$ with $100 \%$ acetonitrile and dried in a Savant SpeedVac for $30 \mathrm{~min}$. Then, the sample was reduced with $10 \mathrm{mM}$ dithioerythritol in $25 \mathrm{mM}$ ammonium bicarbonate for $30 \mathrm{~min}$ at $56^{\circ} \mathrm{C}$ and subsequently alkylated with $55 \mathrm{mM}$ iodoacetamide in 25 $\mathrm{mM}$ ammonium bicarbonate for $20 \mathrm{~min}$ in the dark. Finally, the samples were digested with $12.5 \mathrm{ng} / \mu \mathrm{l}$ sequencing grade trypsin (from Roche Molecular Biochemicals) in $25 \mathrm{mM}$ ammonium bicarbonate ( $\mathrm{pH}$ 8.5) overnight at $37^{\circ} \mathrm{C}$. After digestion, the supernatant was collected and $1 \mu \mathrm{l}$ was spotted onto a MALDI target plate and allowed to air-dry at room temperature. Then, $0.4 \mu \mathrm{l}$ of a $3 \mathrm{mg} / \mathrm{ml} \alpha$-cyano- 4 hydroxy-transcinnamic acid matrix (from Sigma) in $50 \%$ acetonitrile was added to the dried peptide digest and allowed to air-dry again at room temperature. MALDI-TOF MS analyses were performed on a 4700 Proteomics Analyzer MALDI-TOF/TOF mass spectrometer (Applied Biosystems, Framingham, MA, USA) at the Genomics and Proteomics Centre, Complutense University of Madrid (Spain), operated in positive reflector mode, with an accelerating voltage of $20000 \mathrm{~V}$. All mass spectra were calibrated internally using peptides from the autodigestion of trypsin. Analysis by MALDI-TOF/TOF mass spectrometry affords peptide mass fingerprints and the peptides observed can be collated and represented as a list of monoisotopic molecular masses. For protein identification, the non-redundant NCBI database was searched using MASCOT 1.9 (matrixscience.com) through the Global Protein Server v3.5 from Applied Biosystems. The search parameters were: carbamidomethyl cysteine as the fixed modification and oxidized methionine as the variable modification, a peptide mass tolerance 100 p.p.m. and 1 missed trypsin cleavage site. 
Table 1. Purification of GlcNAc-6-P 2-epimerase from E. coli K92

\begin{tabular}{|c|c|c|c|c|c|c|}
\hline Treatment & $\begin{array}{l}\text { Volume } \\
(\mathrm{ml})\end{array}$ & $\begin{array}{l}\text { Protein } \\
(\mathrm{mg})\end{array}$ & $\begin{array}{l}\text { Enzyme } \\
\text { activity } \\
\text { (units) }\end{array}$ & $\begin{array}{l}\text { Specific } \\
\text { activity } \\
\text { (units/mg) }\end{array}$ & $\begin{array}{l}\text { Yield of } \\
\text { recovery } \\
(\%)\end{array}$ & $\begin{array}{l}\text { Purification } \\
\text { (fold) }\end{array}$ \\
\hline Crude extract & 100 & 128 & 3.20 & 0.025 & 100 & 1 \\
\hline Streptomycin sulphate $(0.75 \%)$ & 98 & 112 & 3.02 & 0.026 & 94 & 1 \\
\hline Ammonium sulphate precipitation ( $45 \%)$ & 9 & 22 & 2.09 & 0.130 & 90 & 5 \\
\hline Butyl-agarose & $10(\times 2)^{\mathrm{a}}$ & $3(\times 2)^{\mathrm{a}}$ & $1.80(\times 2)^{\mathrm{a}}$ & 0.60 & 56 & 24 \\
\hline DEAE-FPLC & 4 & 0.16 & 1.2 & 7.50 & 19 & 300 \\
\hline Mannose-6-P-agarose & 2 & 0.02 & 0.6 & 30.00 & 10 & 1200 \\
\hline
\end{tabular}

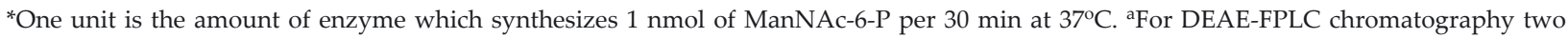
protein pool fractions from Butyl-agarose were used (see Material and Methods section).

In the protein identification, the probability scores were greater than the score fixed as significant, with a p-value of less than 0.05 .

PCR analyses and DNA sequencing. The GlcNAc-6-P 2-epimerase gene was amplified from chromosomal DNA of E. coli K92. Amplification reactions were carried out in a Perkins Elmer DNA Thermal Cycler 2400 with primers engineered to in-

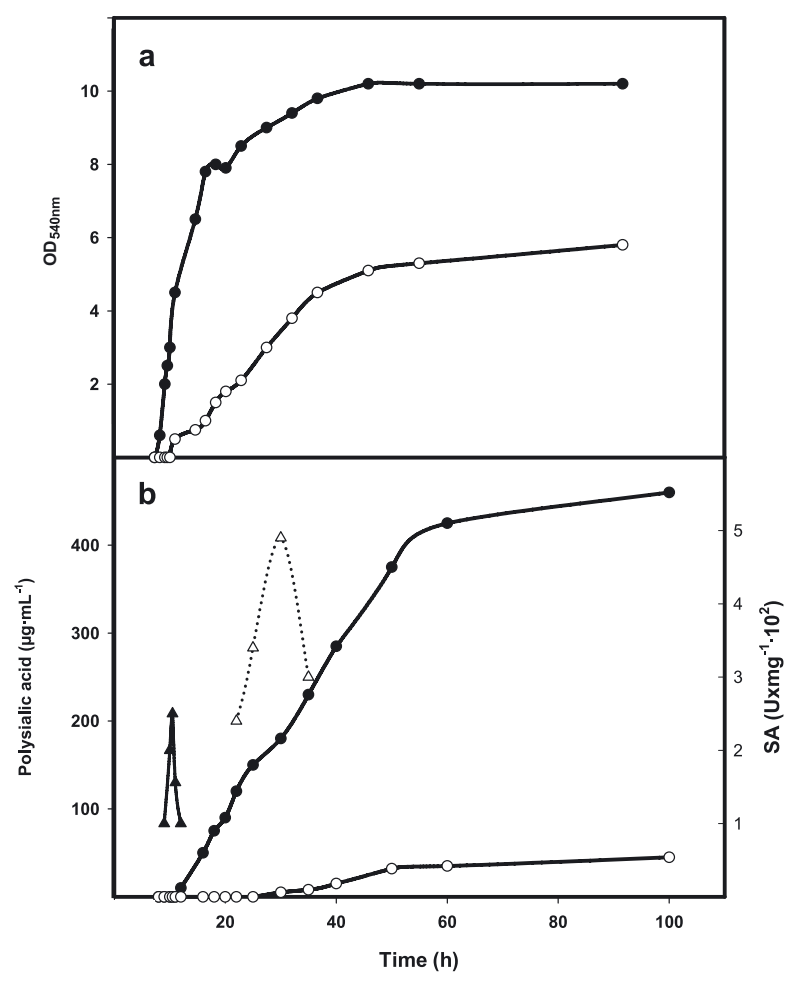

Figure 1. Time course of the appearance of GlcNAc-6-P 2-epimerase.

a) Growth of E. coli $\mathrm{K} 92(\bullet, 0)$; b) Polysialic acid production $(\bullet, \bigcirc)$ and time-course of formation of GlcNAc-6-P 2-epimerase $(\boldsymbol{\Delta}, \Delta)$ when this bacterium was grown at $37^{\circ} \mathrm{C}$ in Xyl-Asn $(\bullet, \boldsymbol{\Delta})$ or ManNAc-Asn $(O, \Delta)$ medium. SA: specific activity. clude desired restriction sites for cloning into pET$42 \mathrm{~b}(+)$ expression vector (Novagen). The primers used were GTCAGTTGCGAATTCCAAAGGAGC (forward) and GGAGAGACTGCAGCGGGTAAATCAG (reverse), which contained an EcoRI and a PstI site, respectively (underlined). PCR reactions were performed under standard conditions.

Specific primers were annealed to chromosomal DNA and incubated with DNA polymerase (Biotools B\&M Labs. S.A.) or Pfu DNA polymerase from Pyrococcus furiosus (Promega) over 35 cycles $\left(30 \mathrm{~s}\right.$ at $24^{\circ} \mathrm{C}, 63 \mathrm{~s} 55^{\circ} \mathrm{C}$ and $120 \mathrm{~s}$ at $72^{\circ} \mathrm{C}$ ). PCR amplification products were analyzed by horizontal agarose gel electrophoresis.

After amplification, the PCR product was digested with EcoRI and PstI, and the resulting fragment was cloned into the corresponding sites of the pET-42b(+) expression vector from Novagen according to the manufacturer's guidelines. The resulting plasmid, pETepim, was transformed into E. coli BL21(DE3) (Novagen) and DH5 $\alpha$.

The plasmid sequence was verified and the insert deemed to be free of PCR errors by sequencing at the Laboratorio of Técnicas Instrumentales (University of León, León, Spain) using DYEnamic ${ }^{\mathrm{TM}}$ ET Dye Terminator Kit (Amersham Biosciences Part of GE Healthcare) according to the Sanger method (Sanger et al., 1977).

\section{RESULTS AND DISCUSSION}

Time course of the appearance of GlcNAc-6-P 2-epimerase during culture

The GlcNAc-6-P 2-epimerase from E. coli K92 began to be synthesized from the early logarithmic phase of growth when this bacterium was incubated at $37^{\circ} \mathrm{C}$ in both $\mathrm{Xyl} / \mathrm{Asn}$, an ideal medium for polysialic acid (PA) production (González-Clemente et al., 
1990), and ManNAc/Asn, which is ideal for induction of the specific ManNAc transport system (RevillaNuín et al., 1999). The level of the enzyme increased linearly during the early logarithmic phase (Fig. 1a), a maximum being reached after 10-11 h (in Xyl-Asn medium) or 29-31 h (ManNAc-Asn medium) of incubation. Thereafter it decreased continuously. This kind of kinetic behaviour, which parallels that of bacterial growth, is very similar to that observed for NeuAc lyase (Ferrero et al., 1996), CMP-synthetase (González-Clemente et al., 1989) and sialyltransferase (Ortíz et al., 1989), other enzymes directly involved in the metabolism of PA by E. coli.

A comparative analysis of such kinetic behaviour revealed that the level of the enzyme was significatively higher (1.9 fold) when E. coli K92 was grown in ManNAc-Asn medium. However, as previously described (Revilla-Nuín et al., 1998b), a dramatic decrease in PA production was recorded $(90 \%)$ (see Fig. 1b). These results confirm the notion that ManNAc is involved in the regulation of capsular polysialic acid biosynthesis (Revilla-Nuín et al., 1998b) and suggest that GlcNAc-6-P 2-epimerase from E. coli $\mathrm{K} 92$ is a ManNAc-inducible enzyme. Moreover, the fact that ManNAc could be the molecule that induces the ManNAc-phosphotransferase transport system (ManNAc-PTS) in this bacterium (Revilla-Nuín et al., 1999), implicates GlcNAc-6-P 2epimerase in the metabolism of ManNAc and Glc-
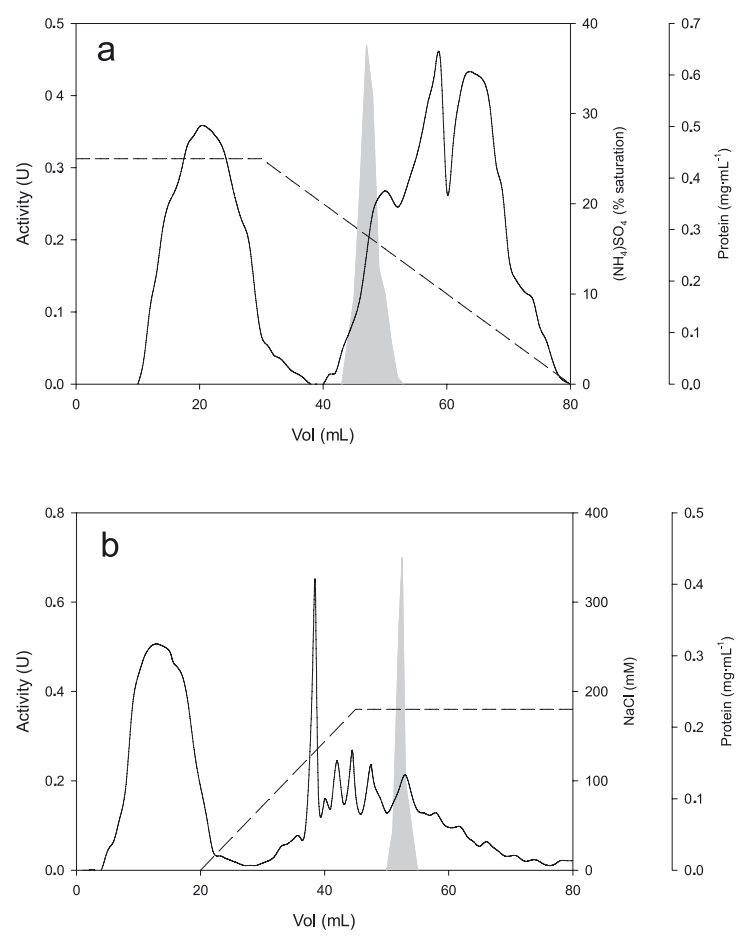

Figure 2. Elution profile of GlcNAc-6-P 2-epimerase from E. coli K92.

Butyl-agarose (a) and DEAE-FPLC (b) columns.
NAc when these sugars are used as carbon sources (see below).

\section{Enzyme purification}

A pure and active GlcNAc-6-P 2-epimerase preparation was obtained from E. coli K92 extracts growth in ManNAc-Asn medium. The purification steps included Butyl-agarose chromatography and anion exchange on DEAE-FPLC (Fig. 2) followed by affinity chromatography on mannose-6-P-agarose. The purification scheme is summarized in Table 1 . In the purification process it was necessary to pool two protein fractions from the Butyl-agarose elution procedure to perform the DEAE-FPLC chromatography. Moreover, exhaustive washes in all chromatographic procedures used were crucial for obtaining good purification results. Although after DEAEchromatography we observed a high level of purification, it was necessary to use the affinity column (mannose-6P-agarose) to obtain a single, sharp electrophoretic (SDS/PAGE) protein band (Fig. 3). Under these conditions (Table 1), the final preparation was 1200 -fold enriched in enzyme activity, with an overall recovery of $10 \%$. Moreover, the use of other gelfiltration, ionic and hydrophobic chromatographic techniques gave no further increases in the specific activity yield of this enzyme (results not show).

\section{Molecular mass determinations}

Analysis of pure GlcNAc-6-P 2-epimerase from E. coli $\mathrm{K} 92$ by SDS/12\%-PAGE revealed a single band with a molecular mass of $38.4 \pm 0.2 \mathrm{kDa}$ (Fig. 3). This result differs from the expected for a pro-

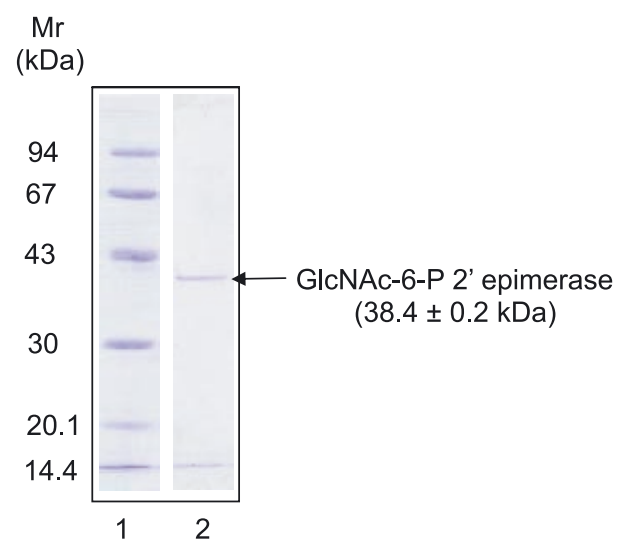

Figure 3. Electrophoretic mobility of purified GlcNAc-6P 2-epimerase from E. coli K92.

Molecular mass standard proteins (phosphorylase $b, 94$ $\mathrm{kDa}$; BSA, $67 \mathrm{kDa}$; ovalbumin, $43 \mathrm{kDa}$; carbonic anhydrase, $30 \mathrm{kDa}$; soybean trypsin inhibitor, $20.1 \mathrm{kDa}$; and $\alpha$ lactalbumin, $14.4 \mathrm{kDa}$ ) (lane 1), and a purified sample of enzyme from Mannose-6-P-agarose chromatography (lane 2) were run on SDS/12\%-PAGE. Proteins were stained with Coomassie Blue R-250. 
Table 2. Amino-acid sequences of tryptic peptides obtained from purified E. coli $\mathrm{K} 92$ GlcNAc-6-P 2-epimerase.

\begin{tabular}{llll}
\hline \multirow{2}{*}{ Peptide } & \multicolumn{2}{l}{ Molecular mass } & \multirow{2}{*}{ Sequence } \\
\cline { 2 - 3 } & (expt) & (calc) & \\
\hline 1 & 1397.72 & 1397.75 & YLYVGVRPEFR \\
2 & 1325.72 & 1325.75 & TLWVPALKQDR \\
3 & 3053.35 & 3053.48 & ICLFTVSDDGHLVAQDPAEVTTVEGAGPR \\
4 & 1350.64 & 1350.67 & WAADIHITPDGR \\
5 & 933.39 & 933.41 & HLYACDR \\
6 & 1288.58 & 1288.60 & EGFQPTETQPR \\
7 & 1803.89 & 1803.93 & GFNVDHSGKYLIAAGQK \\
8 & 2174.06 & 2174.11 & SHHISVYEIVGEQGLLHEK \\
9 & 1642.76 & 1642.79 & YAVGQGPMWVVVNAH \\
\hline
\end{tabular}

tein encoded by nanE, the gene whose product has $28 \mathrm{kDa}$ and which in E. coli has been related to GlcNAc-6-P 2-epimerase activity (Plumbridge \& Vimr, 1999; Kalivoda et al., 2003). The electrophoretic mass
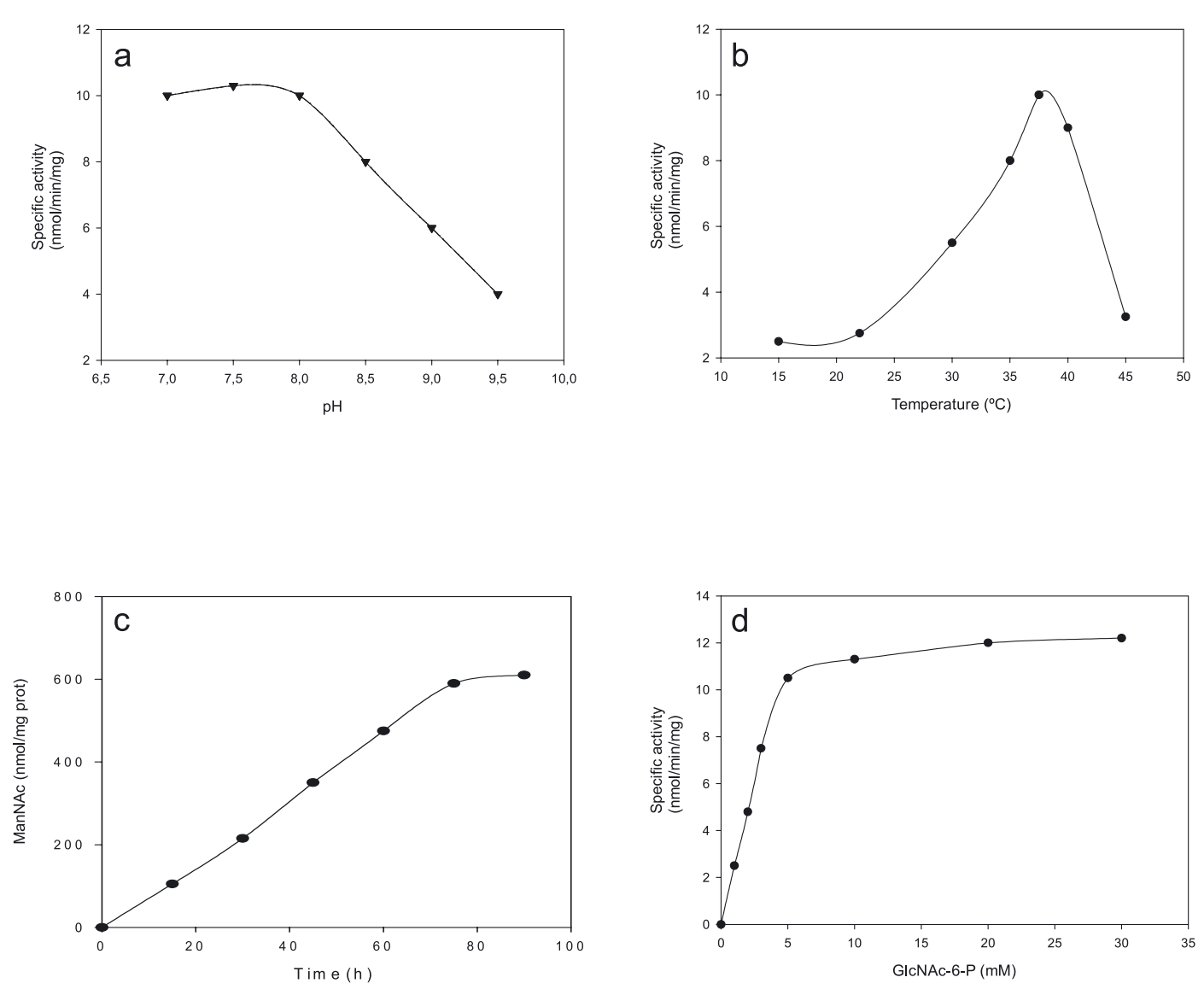

Figure 4. Physicochemical characteristics and kinetic properties of GlcNAc-6-P 2-epimerase from E. coli K92. Effects of $\mathrm{pH}(\mathrm{Tris} / \mathrm{HCl})(\mathrm{a})$, temperature (b), time (c) and substrate concentration (d) on the GlcNAc-6-P 2-epimerase activity from E. coli K92. tein encoded by siaA (40-41 kDa), the gene that has been proposed to code for GlcNAc-6-P 2-epimerase in Neissera meningitidis (Petersen et al., 2000). Different transcriptional origins or post-translational modifications could account for these molecular mass differences.

The molecular mass of native GlcNAc-6-P 2-epimerase from E. coli K92 was determined by gel-filtration chromatography in Shephacryl S-200 (using $10 \mathrm{mM}$ Tris/ $\mathrm{HCl}, \mathrm{pH} 8.0$, as buffer) to be $76 \pm 2 \mathrm{kDa}$. This finding suggests that the active epimerase from E. coli $\mathrm{K} 92$ is a dimeric protein with two similar chains.

\section{Physicochemical characteristics and kinetic properties}

To establish the best conditions for the enzymatic assays, we studied the effect of $\mathrm{pH}$ and temperature on the GlcNAc-6-P 2-epimerase reac-

observed is more similar to the pro- 
Table 3. Comparative amino-acid homologies study of tryptic peptides obtained from purified E. coli K92 GlcNAc-6-P 2-epimerase with non-redundant GenBank CDS Database using BlastP server (NCBI)*

\begin{tabular}{|c|c|c|c|c|}
\hline $\begin{array}{l}\text { Protein } \\
\text { (Da) }\end{array}$ & Description & Ident. \% & Reference & Accession \\
\hline 36677 & $\begin{array}{l}\text { Probable isomerase [imported] - Escherichia coli } \\
\text { (strain O157:H7, substrain EDL933) }\end{array}$ & 100 & Perna et al., 2001 & gil 25497761 \\
\hline 36624 & Putative isomerase [Shigella flexneri 2a str. 301] & 100 & Jin et al., 2002 & gil56479762 \\
\hline 36152 & Putative isomerase [Shigella sonnei Ss046] & 100 & Yang et al., 2005 & $\begin{array}{l}\text { gil } 73854783 \\
\text { gi:74311306 }\end{array}$ \\
\hline 36167 & Putative isomerase [Shigella boydii Sb227] & 100 & Yang et al., 2005 & $\begin{array}{l}\text { gil } 81244626 \\
\text { gi:82543215 }\end{array}$ \\
\hline 36177 & Putative isomerase [Shigella dysenteriae Sd197] & 100 & Yang et al., 2005 & $\begin{array}{l}\text { gil } 81241396 \\
\text { gi:82777248 }\end{array}$ \\
\hline 36177 & 6-Phosphogluconolactonase [Escherichia coli K12] & 100 & $\begin{array}{l}\text { Thomason et al., 2004; } \\
\text { Blattner et al., 1997; } \\
\text { Riley et al., } 2006\end{array}$ & gi|16128735 \\
\hline
\end{tabular}

*Only the ORFs that show $100 \%$ identity.

tion. The highest enzymatic activity was observed at $\mathrm{pH} 7.8$ and a temperature of $37^{\circ} \mathrm{C}$ (Fig. 4). These results are similar to those previously described for GlcNAc-6-P 2-epimerase from E. coli K1 using partially purified protein extracts (Rodríguez-Aparicio et al., 1999) and are in the optimum range of PA production (González-Clemente et al., 1990).

A kinetic analysis revealed that under these conditions product generation by GlcNAc-6-P 2-epimerase was linear up to $60 \mathrm{~min}$ (Fig. 4). Moreover, the enzyme activity displayed a hyperbolic type of behaviour for GlcNAc-6-P (Fig. 4); the $K_{\mathrm{m}}$ calculated for the substrate was $1.5 \mathrm{mM}$. This $K_{\mathrm{m}}$ value, similar to that described for the $E$. coli K1 enzyme (Rodríguez-Aparicio et al., 1999), is in the range of other proteins involved in PA metabolism (Grosh \& Roseman, 1965; Ortíz et al., 1989; Ferrero et al., 1996; Bravo et al., 2001).

\section{Effect of cations and other molecules}

The effect of different cations $(5 \mathrm{mM}$ chloride form) on GlcNAc-6-P 2-epimerase activity from E. coli $\mathrm{K} 92$ was studied. Whereas the addition of monovalent cations such as $\mathrm{K}^{+}, \mathrm{Li}^{+}$and $\mathrm{Rb}^{+}$ to the reaction mixture had no effect, the presence of $\mathrm{Na}^{+}$caused a significant increase in epimerase activity, which was optimum at $10 \mathrm{mM}$ (145\%). This positive effect accounts for the presence of the $\mathrm{Na}^{+}$cation in the reaction mixture (see Material and Methods).

However, the addition of divalent cations to the reaction mixtures, such as $\mathrm{Hg}^{2+}, \mathrm{Cu}^{2+}$,
$\mathrm{Zn}^{2+}, \mathrm{Co}^{2+}, \mathrm{Mg}^{2+}$ and $\mathrm{Mn}^{2+}(5 \mathrm{mM})$ strongly inhibited the enzyme activity (by 95, 70, 85, 72, 53 and $65 \%$ ). The inhibition caused by the heavy metal ions suggests that, as in other proteins (MartínezBlanco et al., 1990; Ferrero et al., 1996; Walters et al., 1999; Bravo et al., 2001; Solana et al., 2001), the presence of $\mathrm{SH}$ groups is essential for catalytic activity. This suggestion is also supported by the strong inhibition (96\%) of epimerase activity caused by $p$-chloromercuribenzoate $(1 \mathrm{mM})$ when added to the epimerase reaction mixture. The significant inhibition caused by $\mathrm{Mg}^{2+}, \mathrm{Mn}^{2+}$ and $\mathrm{Co}^{2+}$ on the GlcNAc-6-P 2-epimerase activity may occur through a similar effect and could be related to the specific characteristics of the epimerase reaction. As previously described (Rodríguez-Aparicio et al., 1992), the specific effect caused by $\mathrm{Mg}^{2+}$ on CMP-sialic acid synthetase from rat liver (another enzyme involved in eukaryotic sialic acid metabolism) can be mimicked by $\mathrm{Mn}^{2+}$ and $\mathrm{Co}^{2+}$. Moreover, the inhibitory effect caused by these cations can be related to the strong decrease in PA production detected (80\%) when E. coli is grown in the presence of $10 \mathrm{mM} \mathrm{Mn}^{2+}$ (Ferrero et al., 1996). Finally, we observed that GlcNAc-6-P 2-epimerase from E. coli $\mathrm{K} 92$ was inhibited by ammonium sulphate, the salt used during the enzyme purification (see above). A concentration of $1.0 \mathrm{M}$ (25\% satn.) caused a $64 \%$ inhibition. This effect, although reversible by desalting the enzyme, requires careful elimination of the ammonium sulphate present in the samples to achieve a good quantification of 2epimerase activity. 
Substrate specificity and effect of different sugars and sugar derivatives

GlcNAc-6-P 2-epimerase from E. coli $\mathrm{K} 92$ showed high specificity for GlcNAc-6-P since this phosphoamino sugar could not be replaced by GlcNAc or UDP-GlcNAc (not shown), another two intimately related amino sugars that can be used as substrates for the enzymatic synthesis of ManNAc (see Introduction). Furthermore, when we used boiled protein extracts in the reaction mixtures no epimerase activity was observed with any of these sugars, indicating that under our assay conditions no enzymatic hydrolysis or epimerization takes place. When other sugars and sugar derivatives were added to the reaction mixture in the presence of GlcNAc-6-P, we observed that monosaccharides (glucose, fructose, mannose, galactose, xylose, arabinose, ribose and sorbose), disaccharides (lactose, melibiose, maltose or sucrose) and sugar derivatives (galactitol, mannitol and sorbitol), or the $\mathrm{N}$ acetyl derivatives $\mathrm{N}$-acetylgalactosamine, GlcNAc, $\mathrm{N}$-acetylneuraminic acid and $\mathrm{N}$-acetylglucosaminitol, or the hexosamines glucosamine and galactosamine did not affect GlcNAc-6-P 2-epimerase activity, even at a concentration of $5 \mathrm{mM}$. However, the addition of mannose-6-P, but not mannose-1-P, to the reaction mixture caused a marked inhibition of enzyme activity. A concentration of mannose-6-P of $5 \mathrm{mM}$, similar to that of GlcNAc-6-P used in the epimerase reaction assays (see Materials and Methods), caused a $50 \%$ inhibition. These results suggest that in vivo GlcNAc-6-P 2-epimerase activity may be specifically regulated by variations in the mannose-6-P intracellular pool.

\section{GlcNAc-6-P 2-epimerase and sialic acid metabolism}

As shown in Fig. 1, when E. coli K92 used ManNAc as a carbon source the amount of GlcNAc6-P 2-epimerase increased up to 1.9 fold. This indicates that our enzyme is directly involved in the intracellular turnover of ManNAc, the amino sugar precursor of sialic acid for capsular PA synthesis.

Different authors have reported that the ManNAc used by E. coli for sialic and polysialic acid biosynthesis is generated by UDP-GlcNAc 2-epimerase (Ringenberg et al., 2003; Vann et al., 2004; Tanner, 2005) and that the phosphorylated form of ManNAc is not involved in this process (Ringenberg et al., 2003). Moreover, the existence in E. coli K92 of a ManNAc-inducible GlcNAc-6-P 2-epimerase and the fact that when this bacterium grew using ManNAc as a carbon source a dramatic decrease in PA production took place (Fig. 1) suggest that, in this bacterium, two different proteins could be involved in sialic acid metabolism: UDP-GlcNAc 2-epimerase for the biosynthetic function and the GlcNAc-6-P 2epimerase described in this work exerting a catabolic role. Thus, when E. coli K92 uptakes ManNAc from the growth medium, the specific and ManNAc-inducible PTS generates intracellular ManNAc-6-P (Revilla-Nuín et al., 1998b), which is used by the GlcNAc6-P 2-epimerase to generate GlcNAc-6-P. Accordingly, the existence of this enzyme, now characterized, may permit this bacterium to use extracellular ManNAc as a carbon source (Revilla-Nuín et al., 1998b; 1999; 2002; Ringenberg et al., 2003). Furthermore, it is very likely that the catabolism of ManNAc would take place via GlcNAc since, as described previously (Revilla-Nuín et al., 1998b; 1999; Ezquerro-Sáenz et al., 2006), when E. coli K92 uses ManNAc, the intracellular pool of ManNAc-6-P and GlcNAc-6-P is increased. Also in favour of this hypothesis is the fact that GlcN-6-P deaminase, an enzyme of the GlcNAc metabolism, is also induced by ManNAc (Biswas et al., 1979). Finally, ManNAc induces both ManNAc-PTS (Revilla-Nuín et al., 1999) and GlcNAc-6-P 2-epimerase expression (Fig. 1), suggesting that, as in ManNAc catabolism, the genes that encode these proteins form part of a regulon that responds to the same regulation signals.

\section{Genetic study}

Different authors have proposed nanE as a putative bacterial gene that codes for GlcNAc-6P 2-epimerase (Plumbridge \& Vimr, 1999; Walters et al., 1999; Kalivoda et al., 2003; Ringenberg et al., 2003). To establish whether GlcNAc-6-P 2-epimerase from E. coli $\mathrm{K} 92$ is indeed codified for this gene, we analyzed the amino-acid sequence of the purified protein. Unfortunately, attempts to sequence the purified GlcNAc-6-P 2-epimerase by N-terminal sequence analysis failed because of amino-terminal blockage. We therefore undertook sequencing by tryptic digestion and mass spectrometry analysis (see Materials and Methods). Table 2 shows the amino-acid sequences of nine peptides obtained from purified GlcNAc-6-P 2-epimerase by tryptic digestion that were compared in a search in a non-redundant NCBI protein sequence database.

A comparative study of these tryptic peptide sequences with a non-redundant GenBank CDS Database (NCBI-BLAST) revealed the existence of a high homology with putative isomerases from different sources (Hayashi et al., 2001; Perna et al., 2001; Jin et al., 2002; Yang et al., 2005) and the $p g l$ gene of E. coli K12 (Thomason et al., 2004) although, surprisingly, not with the epimerases previously related (see above). As shown in Table 3 and Fig. 6, all tryptic peptides obtained showed a complete sequence homology with the recently identified $p g l$ gene from E. coli $\mathrm{K} 12$ and isomerases from different 
E. coli strains and Shigella species. Moreover, in all cases the molecular mass calculated for the respective expected protein products $(36-36.7 \mathrm{kDa})$ were similar to that of the GlcNAc-6-P 2-epimerase purified by us (Table 3 and Fig. 5). However, non-homology was observed when we compared these tryptic peptides sequences with the protein products of nanE and siaA, the two different genes that have been proposed to encode GlcNAc-6-P 2-epimerase in bacteria (Plumbridge \& Vimr, 1999; Walters et al., 1999; Petersen et al., 2000; Kalivoda et al., 2003; Ringenberg et al., 2003) (not shown).

To establish the identity of the gene that codes for the GlcNAc-6-P 2-epimerase from E. coli K92, and using the information obtained from the comparative sequencing studies, we designed different primers that permitted us to amplify, by PCR, a fragment of $1 \mathrm{kbp}$ from E. coli K92 genomic DNA (see Materials and Methods). Cloning and sequencing of this fragment revealed an ORF of $996 \mathrm{nu}-$ cleotides encoding 331 amino acids (Fig. 5), whose

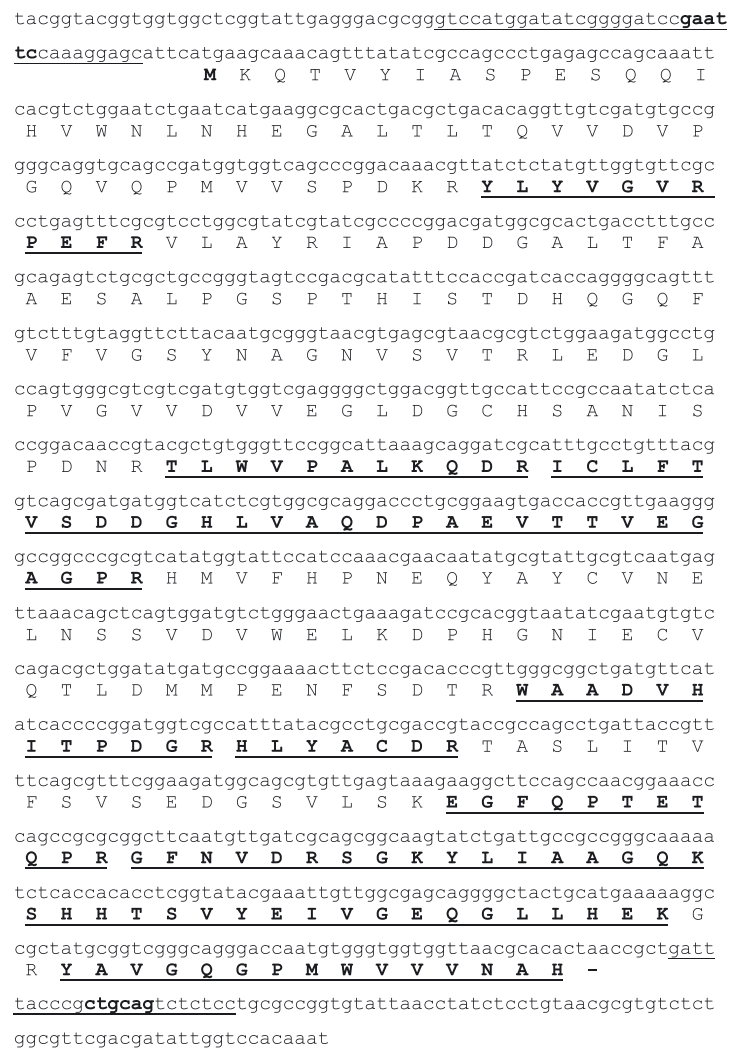

Figure 5. The nucleotide and translated sequence of the PCR-amplified fragment from E. coli K92 genomic DNA. The upper row shows the nucleotide sequence and the second row shows the amino-acid sequence. The nucleotides underlined show the PCR amplification primers (the reverse primer corresponding to the inverse and complementary chain) and the bold nucleotides corresponding to EcoRI and PstI restriction sites. The underlined amino acids show the tryptic peptide sequences of the protein from E. coli K92. calculated mass $(38.4 \pm 0.2 \mathrm{kDa})$ was similar to that obtained by electrophoretic analysis of the GlcNAc6-P 2-epimerase protein purified by us (Fig. 3). A comparison of the amino-acid sequence of this protein with those found in the GenBank CDS Database using BlastP (NCBI) program revealed very high homology with the isomerases from E. coli (strain O157: H7) $(100 \%)$, different Shigella species (98-99\%) and the 6-phosphogluconolactonase ( $\mathrm{pgl}$ gene) from $E$. coli K12 (Fig. 6). However, no isomerase (evaluated as GlcNAc-6-P 2-epimerase) or 6-phosphogluconolactonase activities were detected in protein extracts from $E$. coli BL21 (DE3) and DH5 $\alpha$ transformed with pETepim and induced with IPTG (see Materials and Methods). Moreover, and similar to the comparative tryptic studies, a low degree of amino acid homology was observed with the products of nanE and sia $A$ $(12 \%$ and $11 \%$, respectively) and even with the related UDP-GlcNAc 2-epimerase encoded by the neuC gene $(10 \%)$, the enzyme that generates ManNAc in polysialic acid biosynthesis pathways (Ringenberg et al., 2003; Murkin et al., 2004; Vann et al., 2004). Nevertheless, the fact that by gel-filtration chromatography the native protein (detected by epimerase activity) had a molecular mass of $74-78 \mathrm{kDa}$ - twofold the $38 \mathrm{kDa}$ obtained from SDS/PAGE (denaturing conditions) - precludes the possibility that in the protein amino-acid analysis, a contaminant protein could have been sequenced. If the epimerase purified by us were a product of nanE, the expected molecular mass should be $2 \times 28 \mathrm{kDa}$. However, the molecular mass determined for our native protein was 74-78 $\mathrm{kDa}$. The results obtained from tryptic digestion and peptide sequence analysis revealed the existence of a unique polypeptide chain sequence that showed very high homology with putative isomerases from different bacterial strains. At this juncture, it is also surprising that this protein sequence exhibited high homology with the gene that encodes 6phosphogluconolactonase in E. coli K12 (Table 3 and Fig. 6) i.e., a protein involved in the pentose-P pathway (Thomason et al., 2004). This homology again throws doubt on our results that relate the GlcNAc6-P 2-epimerase with this genetic sequence. However, as reported by Thomason and coworkers in the same work (2004), this genetic sequence product could correspond to a bifunctional protein and, as in Thermoanaerobacter tengcongensis and Vibrio vulnificus $\mathrm{CMCP}$, could show lactonase and isomerase activity. Although nanE has been described in E. coli K12 and, by molecular genetic studies, it has been related to GlcNAc-6-P 2-epimerase (Ringenberg et al., 2003), ManNAc is metabolized by this bacterium very slowly and a previous mutation is required to derepress the gene (Plumbridge \& Vimr, 1999). Nevertheless, E. coli K92 grows very efficiently using ManNAc as a carbon source. As shown in Fig. 1, the use of 
6-P-gluc [ $E$ Coli K12] Isom. ybhE [E. Coli 0157:H7]

Isom. [Sh. dysenteriae Sd197]

Isom. [Sh. sonnei Ss046]

Isom. [Sh. boydii Sb227]

Isom. [Sh. flexneri 2a]

Epim. [E. Coli K92

SiaA [N. meningitidis]

NeuC [ $E$. Coli]

NanE [E. Coli K12]

6-P-gluc [ $E$ Coli K12]

Isom. ybhe [E. Coli 0157:H7]

Isom. [Sh. dysenteriae Sd197]

Isom. [Sh. sonnei Ss046]

Isom. [Sh. boydii Sb227]

Isom. [Sh. flexneri 2a]

Epim. [E. Coli K92]

SiaA [N. meningitidis]

NeuC $[E . C O I i]$

NanE [E. Coli K12]

6-P-gluc [ $E$ coli K12]

Isom. ybhE [E. Coli 0157:H7]

Isom. [Sh. dysenteriae Sd197]

Isom. [Sh. sonnei Ss046]

Isom. [Sh. boydii Sb227]

Isom. [Sh. flexneri 2a]

Epim. [E. Coli K92]

SiaA [N. meningitidis]

NeuC $[E . C O l i]$

NanE $[E . \operatorname{Coli} \mathrm{K} 12]$

6-P-gluc [E coli K12]

Isom. ybhE [E. Coli 0157:H7]

Isom. [Sh. dysenteriae Sd197]

Isom. [Sh. sonnei Ss046]

Isom. [Shigella boydii Sb227]

Isom. [Sh. flexneri 2a]

Epim. [E. Coli K92]

SiaA [ $N$. meningitidis]

NeuC $[E . C O l i]$

NanE $[E$. Coli K12]

6-P-gluc [ $\left[\begin{array}{ccc}\text { COli K12] } & \text { K }\end{array}\right.$

Isom. ybhE [E. Coli 0157:H7]

Isom. [Sh. dysenteriae Sd197]

Isom. [Sh. sonnei Ss046]

Isom. [Shigella boydii Sb227]

Isom. [Sh. flexneri 2a]

Epim. [E. Coli K92]

SiaA [N. meningitidis]

NeuC_[E.COIi

NanE ${ }^{-}[E$. Coli K12]

6-P-gluc [E Coli K12

Isom. ybhe [E. Coli 0157:H7]

Isom. [Sh. dysenteriae Sd197]

Isom. [Sh. sonnei ss046]

Isom. [Sh. boydii Sb227]

Isom. [Sh. flexneri 2a]

Epim. [E. Coli K92]

SiaA [N. meningitidis]

NeuC $[E . C o l i]$

NanE [E. Coli K12]

6-P-gluc [ $E$ Coli K12]

Isom. ybhE [E. Coli 0157:H7]

Isom. [Sh. dysenteriae sd197]

Isom. [Sh. sonnei Ss046]

Isom. [Sh. boydii Sb227]

Isom. [Sh. flexneri 2a]

Epim. [E. Coli K92]

SiaA [N. meningitidis]

NeuC [E.Coli]

NanE [E. Coli K12]

6-P-gluc [ $E$ coli K12]

Isom. ybhE [E. Coli O157:H7]

Isom. [Sh. dysenteriae Sd197]

Isom. [Sh. sonnei Ss046]

Isom. [Sh. boydii Sb227]

Isom. [Sh. flexneri 2a]

Epim. [E. Coli K92]

SiaA [N. meningitidis]

NeuC $[E . C O l i]$

NanE ${ }^{-}[E$. Coli K12]
MKQTVYIASPESQQ-----IHVWNLNHEG-----ALTLTQVVDVPGQVQP 40 MKQTVYIASPESQQ-----IHVWNLNHEG-----ALTLTQVVDVPGQVQP 40 MKQTVYIASPESQQ-----IHVWNLNHEG-----ALTLTQVVDVPGQVQP 40 MKQTVYIASPESQQ-----IHVWNLNHEG-----ALTLTOVVDVPGQVQP 40 MKOTVYIASPESQQ-----IHVWNLNHEG-----ALTLTOVVDVPGQVQP 40 MKQIVYIASPESQQ-----IHVWNLNHEG----ALILIQVVDVPGQVQP 40 MKQTVYIASPESQQ--_-IHVWNLNHEG----ALTLTQVVDVPGQVQP 40 MKQTVY IAS PESQQ-----I IHVWNLNHEG-----ALTLTQVVDVPGQVQP 40 MKRILCITGTRADFGKLKPLLAYIENHPDLELHLIVTGMHMMKTYGRTYK 50 MKKI LYVTGSRAEYGIVRRLLTMLRETPE IQLDLAVTGMHCDNAYGNTIH 50

MVVSPDKRYLYVGVRPEFRVLAYRIAPDDGALTFAAESALPG---SPTHI 87 MVVSPDKRYLYVGVRPEFRVLAYRIAPDDGAITFAAEXALPG---SPTHI 87 MVVSPDKRYLYVGVRPEFRVLAYRIAPDDGALTFAAESALPG---SPTHI 87 $\begin{array}{ll}\text { MVVSPDKRYLYVGVRPEFRVLAYRIAPDDGALTFAAESALPG---SPTHI } & 87\end{array}$ MVVSPDKRYLYVGVRPEFRVLAYRIAPDDGALTEAAESALPG---SPTHI 87 MVVSPDKRYLYVGVRPEFRVLAYRIAPDDGALTFAAESVLPG---SPTHI 87 MVVSPDKRYLYVGVRPEFRVLAYRIAPDDGALTFAAESALPG---SPTHI 87 EVTRENYOHTYL FSNOIOCERMAVICNTITFISRISDETFP--DMVMI 97 I IEQDNFNI IKVVDININTTSHTH I LHSMSVCLNSFGDFF SNNTYDAVMV 10

$$
: \text {. }
$$

STDHQGQFVFVGSYNAGNVSVTRLEDGL-PVGVVD-----VVEGLDGCHS 131 STDHQGQFVFVGSYNAGNVSVTRLEDGL-PVGVVD-----VVEGLDGCHS 131 STDHQGQFVFVGSYNAGNVSVTRLEDGL-PVGVVD-----VVEGLDGCHS 131 STDHOGQFVFVGSYNAGNVSVTRIFDGL-PVGVVD-_-_-VVEGIDCCHS 131 STDHQGQFVVGSYNAT 13 STDHQGQFVGSYNAGNVSVRLEDGL-PVGVVD-UVELDGCHS 131 STDHQGQFVFVGSYNAGNVSVIRLEDGL-PVGVVD-----VVEGLDGCHS 131 STDHQGQFVFVGSYNAGNVSVTRLEDGL-PVGVVD-----VVEGLDGCHS 131 HGDRLEALAGAAVGALSSRLVCHIEGGE-LSGTVDDSIRHSISKLSHIHL 146 LGDRYE IFSVA IAASMHNI PLIHI HGGEKTLANYDEFIRHSITKMSKLHL 150 LDKPEIVAAMALAAEQAGAVAIRIEGVA-----------NLQATR---- 62

$$
:: \text {. }
$$

ANISPDNRTLWVPALKODRICLFTVSDDGHLVAODPAEVTTVEG------ 175 ANISPDNRTLWVPALKODRICLFTVSDDGHLVAODPAEVTTVEG--_--- 175 ANISPDNRTLWVPALKQDRICLFTVSDDGHLVAQDPAEVTTVEG------ 175 ANISPDNRTLWVPALKQDRICLFTVSDDGHLVAQDPAEVTTVEG------ 175 ANIS PDNRTLWVPALKQDRICLFTVSDDGHLVAQDPAEVTTIEG------ 175 ANIS PDNRTLWVPALKQDRICLFTVSDDGHLVAQDPAEVTTVEG------ 175 ANISPDNRTLWVPALKQDRICLFTVSDDGHLVAQDPAEVTTVEG--_--- 175 VANEQAVTRLVOMGEKRKHIHIIGSPDLDVMASSTLPSLEEVKEYYGLPY 196 TSTEEYKKRVIOLGEKPGSVFNIGSLGAENALSLHLPNKOELELKYGSLI 200 $\begin{array}{ll}\text { TSTEEYKKRVIQLGEKPGSVFNIGSLGAENALSLHLPNKQELELKYGSLL } & 200 \\ \text { AVVSVPIIGIVKRDLEDSPVRITAYIEDVDALAQAGADIIAIDG------ } 106\end{array}$

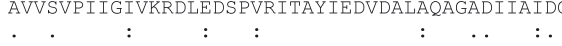

AGPRHMVEHPNEQYAYCVNELNSS--------------VDVWELKDPHGN 211 AGPRHMVFHPNEQYAYCVNELNSS--------------VDVWELKDPHGN 211 AGPRHMVFHPNEQYAYCVNELNSS-------------VDVWELKDPHGN 211 AGPRHMVFHPNEQYAYCVNELNSS-------------VDVWELKDPHGN 211 AGPRHMVFHPNEOYAYCVNEINSS-AGPRHMV HPNEQYAYCVNELNSS-- - - - - -21 AGPRHMVEHPNEQYAYCVNELNSS--------VDVWELKDPHGN 21 AGPRHMVFHPNEQYAYCVNELNSSENYGISMFHPVTTEAHLMPQYAAQYFKALELSG--QNI ISIYPNNDTGTE 24 KRYFVVVFHPETLSTQSVNDQIDELLSAISFFKNTHDFIFIGSNADTGSD 250 ----TDRPRPVPVETLLARIHHHG-----------LLAMTDCSTPEDG 139

$$
:^{\star} \quad:
$$$$
::
$$

IECVQTLDMMPE-NFSDT-RWAADIHITPDGRHLYACDRTASLITVFSVS 259 IECVOTLDMMPE-NFSDT-RWAADIHITPDGRHLYACDRTASLITVFSVS 259 IECVQTLDMMPE-NFSDT-RWAADIHITPDGRHLYACDRTASLITVFSVS 259 IECVQTLDMMPE-NFSDT-CWAADIHITPDGRHLYACDRTASLITVFSVS 259

IECVQTLDMMPE-NFSDT-RWAADIHITPDGRHLYACDRTASLITVFSVS 259 IECVQTLDMMPE-NFSDT-RWAADIHITPDGRHLYACDRTASLITVFSVS 259 IECVILDMME-NESDT-RMAADVHITDGRHLYACDRTASLITVESVS 25 SILQELLKYQSD-KFIAEPSIREEYLVLLKHAKFMVGNSSAGIREAPLY 293 I IQRKVKYFCKEYKFRYLISIRSEDYLAMIKYSCGLIGNSSSGLIEVPSL 300 LACQKLGAEIIG---------------TTLSGYTTPETPEEPDL 168 . : : .

EDGSVLSKEGEQPTETQPRGFNVDHSGKYLIAAG---QKSHHISVYEIVG 306 EDGSVLSKEGFOPTETOPRGFNIDHRGKYLIAAG---OKSHHISVYEIVG 306 EDCSVISKEGFQRTETORRCENVDHSCKYLIAAG--OKSHHTSVYETVC 306 DCSVISKECEQPTETQPRCFVDHSCKYLIAAG---QKSHHISVYEIVG 306 EDGSVLSKEGFQPTETQPRGFNVDHSGKYLIAAG---QKSHLISVYEIVG 306 EDGSVLSKEGFQPTETQPRGFNVDYSGKYLIAAG---QKSHHISVYEIVG 306 EDGSVLSKEGFQPTETQPRGFNVDRSGKYLIAAG---QKSHHTSVYEIVG 306 GVPS IDVGTRQNNRHMGKS I IHTDYETKNIFDAI---QQACSLGKFEADD 340 KVATINIGDRQKGRVRGASVIDVPVEKNAIVRGINISQDEKFISVVQSSS 350 ALVKTLSDAG--CRVIAEGRYNTPAQAADAMRHG---------------- 200

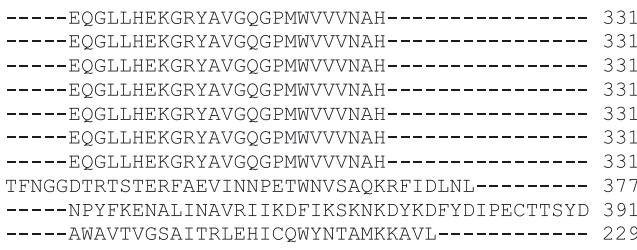


Xyl or ManNAc as a source of carbon did not elicit significant delays in growth, suggesting that unlike E. coli $\mathrm{K} 12$, in E. coli $\mathrm{K} 92$ the genetic derepression through mutation is not necessary for the growth of this bacterium on ManNAc. Moreover, as previously described (Plumbridge \& Vimr, 1999), for E. coli K12 to grow using ManNAc it is also necessary that the multispecific transport system that uptakes this amino sugar in this bacterium (ManXYZ) should be derepressed by an mlc mutation. In E. coli K92 this previous gene derepression is not necessary since in this bacterium the uptake of ManNAc is carried out by a different transport system that is very specific, induced by ManNAc-6-P, and much more efficient than the ManXYZ transporter (Revilla-Nuín et al., 1999; 2002). All these metabolic differences support the idea that, as proposed, the protein purified by us would be the putative isomerase reported (Table 3) and that it would be responsible for the GlcNAc-6$\mathrm{P}$ 2-epimerase activity in E. coli K92. Although in E. coli $\mathrm{K} 92$ we have observed the presence of nanE (we detected it by PCR analysis, results not shown), it is possible that this gene might be repressed, as in E. coli K12, and that both the specific ManNAc-PTS transport system and the epimerase related in this work could be responsible for the efficient growth of this bacterium when it uses ManNAc as a carbon source. Thus, E. coli $\mathrm{K} 92$ has evolved by developing a new strategy that permits good cellular growth using ManNAc as a carbon source without having to depend on previous mutations. Expression studies by mRNA quantification and by direct reaction of the respective protein products with specific antibodies, analysis of enzymatic activities, and the use of knockout bacteria in these genes should provide key data to confirm these hypotheses and to establish the exact role these genes play in bacterial amino sugar metabolism. Further research in this topic is currently in progress.

\section{Acknowledgements}

We are gratefully indebted to Mrs. D. Gutiérrez Blázquez for her participation in the protein tryptic digestion analysis.

This work was supported by grants from the Dirección General de Investigación (BMC2003-03575) and the Junta de Castilla y León (JCyL LE 44/04).

\section{REFERENCES}

Biswas M, Singh B, Datta A (1979) Induction of N-acetylmannosamine catabolic pathway in yeast. Biochim Biophys Acta 585: 535-542.

Blattner FR, Plunkett G III, Bloch CA, Perna NT, Burland V, Riley M, Collado-Vides J, Glasner JD, Rode CK, Mayhew GF, Gregor J, Davis NW, Kirkpatrick HA, Goeden MA, Rose DJ, Mau B, Shao Y (1997). The complete genome sequence of Escherichia coli K-12. Science 277: 1453-1474.

Blume A, Benei AJ, Stolz F, Schmidt RR, Reutter W (2004) Characterization of ligand binding to the bifunctional key enzyme in the sialic acid biosynthesis by NMR. J Biol Chem 279: 55715-55721.

Bork K, Reutter W, Gerardy-Schahn R, Horstkorte R (2005) The intracellular concentration of sialic acid regulates the polysialylation of the neural cell adhesion molecule. FEBS Lett 579: 5079-5083.

Bradford MM (1976) A rapid and sensitive method for the quantitation of microgram quantities of protein utilizing the principle of protein-dye binding. Anal Biochem 72: 248-254.

Bravo IG, Barrallo S, Ferrero MA, Rodríguez-Aparicio LB, Martínez-Blanco H, Reglero A (2001) Kinetic properties of the acylneuraminate cytidylyltransferase from Pasteurella haemolytica A2. Biochem J 358: 585-598.

Chou WK, Hinderlich S, Reutter W, Tanner ME (2003) Sialic acid biosynthesis: stereochemistry and mechanism of the reaction catalyzed by the mammalian UDP-N-acetylglucosamine 2-epimerase. J Am Chem Soc 125: 2455-2461.

Corfield AP, Schauer R (1982) Occurrence of sialic acids. In Sialic Acids. Chemistry, Metabolism and Function (Schauer R, ed) pp 5-50. Springer-Verlag, New York.

Ezquerro-Sáenz C, Ferrero MA, Revilla-Nuín B, LópezVelasco FF, Martínez-Blanco H, Rodríguez-Aparicio LB (2006) Transport of $N$-acetyl-D-galactosamine in Escherichia coli K92: effect on acetyl-amino sugar metabolism and polysialic acid production. Biochimie 88: 95-102.

Ferrero MA, Reglero A, Fernández-López M, Ordás R, Rodríguez-Aparicio LB (1996) N-Acetyl-D-neuraminic acid lyase generates the sialic acid for colominic acid biosynthesis in Escherichia coli K1. Biochem J 317: 157-165.

González-Clemente C, Luengo JM, Rodríguez-Aparicio LB, Reglero A (1989) Regulation of colominic acid biosynthesis by temperature: role of cytidine 5 '-monophosphate $N$-acetylneuraminic acid synthetase. FEBS Lett 250: 429-432.

González-Clemente C, Luengo JM, Rodríguez-Aparicio LB, Ferrero MA, Reglero A (1990) High production of polysialic acid [Neu5Ac $\alpha(2-8)-\operatorname{Neu} 5 \mathrm{Ac} \alpha(2-9)]_{\mathrm{n}}$ by Escherichia coli $\mathrm{K} 92$ grown in a chemically defined médium. Biol Chem Hoppe-Seyler 371: 1101-1106.

Grosh S, Roseman S (1965) The sialic acids. IV N-acyl-Dglucosamine 6-phosphate 2-epimerase. J Biol Chem 240: $1525-1530$

\section{Figure 6. Protein sequence alignment (CLUSTALW) of GlcNAc-6-P 2-epimerase of E. coli K92.}

Alignment with other related bacterial epimerase proteins involved in ManNAc metabolism (NeuC, SiaA and NanE) and isomerases from E. coli strain O157:H7 (Hayashi et al., 2001; Perna et al., 2001), Sh. dysenteriae Sd197 (Yang et al., 2005), S. sonnei Ss046 (Yang et al., 2005), S. boydii Sb227 (Jin et al., 2002), S. flexneri 2a (Yang et al., 2005) and 6-phosphogluconolactonase of E. coli K12 (Blattner et al., 1997; Thomason et al., 2004; Riley et al., 2006). NeuC: UDP-N-acetylglucosamine 2epimerase from E. coli (Vann et al., 2004); NanE: predicted $N$-acetylmannosamine-6-P epimerase from E. coli (Walters et al., 1999); SiaA: N-acetylmannosamine-6-P 2-epimerase from N. meningitidis serogroup B (Petersen et al., 2000). Isom.: putative isomerase. Epim.: epimerase. 6-P-gluc.: 6-phosphogluconolactonase. Identical amino acids $\left({ }^{*}\right)$, conservative amino acid changes (:), amino acid related (.), and lack of similarity (blank space) are indicated. 
Hayashi T, Makino K, Ohnishi M, Kurokawa K, Ishii K, Yokoyama K, Han CG, Ohtsubo E, Nakayama K, Murata $\mathrm{T}$, Tanaka $\mathrm{M}$, Tobe $\mathrm{T}$, Iida $\mathrm{T}$, Takami $\mathrm{H}$, Honda T, Sasakawa C, Ogasawara N, Yasunaga T, Kuhara S, Shiba T, Hattori M, Shinagawa H (2001) Complete genome sequence of enterohemorrhagic Escherichia coli O157:H7 and genomic comparison with a laboratory strain K-12. DNA Res 8: 11-22.

Hewick RM, Hunkapiller MW, Hood LE, Dreyer WJ (1981) A gas-liquid solid phase peptide and protein sequenator. J Biol Chem 256: 7990-7997.

Hinderlich S, Stasche R, Zeitler R, Reutter W (1997) A bifunctional enzyme catalyzes the first two steps in $\mathrm{N}$ acetylneuraminic acid biosynthesis of rat liver. Purification and characterization of UDP- $N$-acetylglucosamine 2-epimerase/N-acetyl-mannosamine kinase. J Biol Chem 272: 24313-24318.

Hinderlich S, Nöring S, Weise Ch, Franke P, Stäsche R, Reuter W (1998) Purification and characterization of $\mathrm{N}$-acetylglucosamine kinase from rat liver. Comparison with UDP- $N$-acetylglucosamine 2-epimerase/ $\mathrm{N}$-acetylmannosamine kinase. Eur J Biochem 252: 133-139.

Itoh T, Mikami B, Maru I, Ohta Y, Hashimoto W, Murata K (2000) Crystal structure of $N$-acyl-D-glucosamine 2epimerase from porcine kidney at $2.0 \AA$ resolution. J Mol Biol 303: 733-744.

Jin Q, Yuan Z, Xu J, Wang Y, Shen Y, Lu W, Wang J, Liu $\mathrm{H}$, Yang J, Yang $\mathrm{F}$, Zhang $X$, Zhang J, Yang $G$, Wu $H$, Qu D, Dong J, Sun L, Xue Y, Zhao A, Gao Y, Zhu J, Kan B, Ding K, Chen S, Cheng H, Yao Z, He B, Chen R, Ma D, Qiang B, Wen Y, Hou Y, Yu J (2002) Genome sequence of Shigella flexneri 2a: insights into pathogenicity through comparison with genomes of Escherichia coli K12 and O157. Nucleic Acids Res 30: 4432-4441.

Kalivoda KA, Steenbergen SM, Vimr ER, Plumbridge J (2003) Regulation of sialic acid catabolism by the DNA binding protein NanR in Escherichia coli. J Bacteriol 185: 4806-4815.

Kupor SR, Fraenkel DG (1969) 6-Phosphogluconolactonase mutants of Escherichia coli and a maltose blue gene. J Bacteriol 100: 1296-1301.

Laemmli UK (1970) Cleavage of structural proteins during the assembly of the head of bacteriophage T4. Nature 227: 680-685.

Luchansky SJ, Yarema KJ, Takahashi S, Bertozzi CR (2003) GlcNAc 2-epimerase can serve a catabolic role in sialic acid metabolism. J Biol Chem 278: 8035-8042.

Martínez-Blanco H, Reglero A, Rodríguez-Aparicio LB, Luengo JM (1990) Purification and biochemical characterization of phenylacetyl-CoA ligase from Pseudomonas putida. J Biol Chem 265: 7084-7090.

Maru I, Ohta Y, Murata K, Tsukada Y (1996) Molecular cloning and identification of $N$-acyl-D-glucosamine 2epimerase from porcine kidney as a rennin-binding protein. J Biol Chem 271: 16294-16299.

Maru I, Ohnishi J, Ohta Y, Tsukada Y (2002) Why is sialic acid attracting interest now? Complete enzymatic synthesis of sialic acid with $\mathrm{N}$-acetylglucosamine 2-epimerase. J Biosci Bioeng 93: 258-265.

Mullis KB, Faloona FA (1987) Specific synthesis of DNA in vitro via a polymerase-catalyzed chain reaction. Meth Enzymol 155: 335-350.

Murkin AS, Chou WK, Wakarchuk W, Tanner ME (2004) Identification and mechanism of a bacterial hydrolyzing UDP-N-acetylglucosamine 2-epimerase. Biochemistry 43: 14290-14298.

Noguchi S, Keira Y, Murayama K, Ogawa M, Fujita M, Kawahara G, Oya Y, Imazawa M, Goto Y, Hayashi YK, Nonaka I, Nishino I (2004) Reduction of UDP-N- acetylglucosamine 2-epimerase/ $\mathrm{N}$-acetylmannosamine kinase activity and sialylation in distal myopathy with rimmed vacuoles. J Biol Chem 279: 11402-11407.

Ortiz AI, Reglero A, Rodríguez-Aparicio LB, Luengo JM (1989) In vitro synthesis of colominic acid by membrane-bound sialyltransferase of Escherichia coli K-235. Eur J Biochem 178: 741-749.

Perna NT, Plunkett G III, Burland V, Mau B, Glasner JD, Rose DJ, Mayhew GF, Evans PS, Gregor J, Kirkpatrick HA, Posfai G, Hackett J, Klink S, Boutin A, Shao Y, Miller L, Grotbeck EJ, Davis NW, Lim A, Dimalanta ET, Potamousis KD, Apodaca J, Anantharaman TS, Lin J, Yen G, Schwartz DC, Welch RA, Blattner FR (2001) Genome sequence of enterohaemorrhagic Escherichia coli O157:H7. Nature 409: 529-533.

Petersen M, Fessner WD, Frosch M, Lüneberg E (2000) The siaA gene involved in capsule polysaccharide biosynthesis of Neisseria meningitides B codes for $\mathrm{N}$-acetylglucosamine-6-phosphate 2-epimerase activity. FEMS Microbiol Lett 184: 161-164.

Plumbridge J, Vimr E (1999) Convergent pathways for utilization of the amino sugars $N$-acetylglucosamine, $\mathrm{N}$-acetylmannosamine and $N$-acetylneuraminic acid by Escherichia coli. J Bacteriol 181: 47-54.

Reutter W, Köttgen E, Bouer C, Gerok W (1982) Biological significance of sialic acids. In Sialic Acids. Chemistry, Metabolism and Function (Schauer R, ed) pp 263-306. Springer-Verlag, New York.

Revilla-Nuin B, Reglero A, Feo JC, Rodríguez-Aparicio LB, Ferrero MA (1998a) Identification, expression and tissue distribution of cytidine 5 -monophosphate $\mathrm{N}$ acetylneuraminic acid synthetase activity in the rat. Glycoconjugate J 15: 233-241.

Revilla-Nuín B, Rodríguez-Aparicio LB, Ferrero MA, Reglero A (1998b) Regulation of capsular polysialic acid biosynthesis by $N$-acetyl-D-mannosamine, an intermediate of sialic acid metabolism. FEBS Lett 426: 191-195.

Revilla-Nuin B, Reglero A, Ferrero MA, Rodríguez-Aparicio LB (1999) Uptake of $N$-acetyl-D-mannosamine: an essential intermediate in polysialic acid biosynthesis by Escherichia coli K92. FEBS Lett 449: 183-186.

Revilla-Nuin B, Reglero A, Martínez-Blanco H, Bravo IG, Ferrero MA, Rodriguez-Aparicio LB (2002) Transport of $\mathrm{N}$-acetyl-D-mannosamine and $\mathrm{N}$-acetyl-D-glucosamine in Escherichia coli K1: effect on capsular polysialic acid production. FEBS Lett 511: 97-101.

Riley M, Abe T, Arnaud MB, Berlyn MK, Blattner FR, Chaudhuri RR, Glasner JD, Horiuchi T, Keseler IM, Kosuge T, Mori H, Perna NT, Plunkett G, Rudd KE, Serres MH, Thomas GH, Thomson NR, Wishart D, Wanner BL (2006) Escherichia coli K-12: a cooperatively developed annotation snapshot-2005. Nucleic Acids Res 34: 1-9.

Ringenberg MA, Steenbergen SM, Vimr WR (2003) The first committed step in the biosynthesis of sialic acid by Escherichia coli K1 does not involve a phosphorylated $\mathrm{N}$-acetylmannosamine intermediate. Mol Microbiol 50: 961-975.

Rodríguez-Aparicio LB, Reglero A, Luengo JM (1987) Uptake of $N$-acetylneuraminic acid by Escherichia coli K235. Biochemical characterization of the transport system. Biochem J 246: 287-294.

Rodríguez-Aparicio LB, Reglero A, Ortiz AI, Luengo JM (1988) Effect of physical and chemical conditions on the production of colominic acid by Escherichia coli in a defined medium. Appl Microbiol Biotechnol 27: 474-483.

Rodríguez-Aparicio LB, Luengo JM, González-Clemente C, Reglero A (1992) Purification and characterization of the nuclear cytidine 5'-monophosphate $N$-acetylneur- 
aminic acid synthetase from rat liver. J Biol Chem 267: 9257-9263.

Rodríguez-Aparicio LB, Ferrero MA, Revilla-Nuin B, Martínez-Blanco H, Reglero A (1999) Determination of different amino sugar 2-epimerase activities by coupling to $N$-acetylneuraminate synthesis. Biochim Biophys Acta 1428: 305-313.

Rutishauser U (1993) Regulation of cell-cell interactions by NCAM and its polysialic acid moiety. In Polysialic Acid (Roth J, Rutishauser U, Troy FA, eds) pp 215-227. Birkhäuser Verlag, Germany.

Sambrook J, Fritsch EF, Maniatis T (1989) Molecular Cloning: a Laboratory Manual, 2nd ed. Cold Spring Harbor Laboratory Press, Cold Spring Harbor, New York.

Sanger F, Nicklen S, Coulson AR (1977) DNA sequencing with chain-terminating inhibitors. Proc Natl Acad Sci USA 74: 5463-5467.

Shevchenko A, Chernushevich I, Wilm M, Mann M (2000) In Protein in Peptide Analysis (Chapman JR, ed) vol 146, pp 116. Human Press, Totowa, New Jork.

Solana S, Reglero A, Martínez-Blanco H, Revilla-Nuín B, Bravo IG, Rodríguez-Aparicio LB, Ferrero MA (2001) N-Acetylneuraminic acid uptake in Pasteurella (Mannheimia) haemolytica A2 occurs by an inducible and specific transport system. FEBS Lett 509: 41-46.

Stasche R, Hinderlich S, Weise C, Effertz K, Lucka L, Moormann P, Reutter W (1997) A bifunctional enzyme catalyzes the first two steps in $\mathrm{N}$-acetylneuraminic acid biosynthesis of rat liver. Molecular cloning and functional expression of UDP- $N$-acetyl-glucosamine 2-epimerase/ $N$-acetylmannosamine kinase. J Biol Chem 272: 24319-24324.

Svennerholm L (1958) Quantitative estimation of sialic acids. Acta Chem Scand 12: 547-554.

Tanner ME (2005) The enzymes of sialic acid biosynthesis. Bioorg Chem 33: 216-228.
Thomason LC, Court DL, Datta AR, Khanna R, Rosner JL (2004) Identification of Escherichia coli K12 ybhE gene as $\mathrm{pgl}$, encoding 6-phosphogluconolactonase. J Bacteriol 186: 8248-8253.

Van Rinsum J, Van Dijk W, Hoogwinkel JM, Ferwerda W (1983) Subcellular localization and tissue distribution of sialic acid precursor-forming enzymes. Biochem J 210: 21-28.

Vann WF, Zapata G, Boulnois R, Silver RP (1993) Structure and function of enzymes in sialic acid metabolism in polysialic producing bacteria. In Polysialic Acid (Roth J, Rutishauser U, Troy FA, eds) pp 125-136. Birkhäuser Verlag, Germany.

Vann WF, Daines DA, Murkin AS, Tanner ME, Chaffin DO, Rubens CE, Vionnet J, Silver RP (2004) The neuC protein of Escherichia coli $\mathrm{K} 1$ is a UDP $\mathrm{N}$-acetylglucosamine 2-epimerase. J Bacteriol 186: 706-712.

Viswanathan K, Narang S, Hinderlich S, Lee YC, Betenbaugh MJ (2005) Engineering intracellular CMP-sialic acid metabolism into insect cells and methods to enhance its generation. Biochemistry 44: 7526-7534.

Walters DM, Stirewalt VL, Melville SB (1999) Cloning, sequence, and transcriptional regulation of the operon encoding a putative $\mathrm{N}$-acetylmannosamine-6-phosphate epimerase (nanE) and sialic acid lyase (nanA) in Clostridium perfringens. J Bacteriol 181: 4526-4532.

Warren L (1959) The thiobarbituric acid assay of sialic acids. J Biol Chem 234: 1971-1975.

Yang F, Yang J, Zhang X, Chen L, Jiang Y, Yan Y, Tang X, Wang J, Xiong Z, Dong J, Xue Y, Zhu Y, Xu X, Sun L, Chen S, Nie H, Peng J, Xu J, Wang Y, Yuan Z, Wen Y, Yao Z, Shen Y, Qiang B, Hou Y, Yu J, Jin Q (2005) Genome dynamics and diversity of Shigella species, the etiologic agents of bacillary dysentery. Nucleic Acids Res 33: 6445-6458. 